\title{
The Participation of Society and Students' Parents in Education Organizing at State 2 Sekayam Senior High School
}

\author{
Heri Priyanto $^{1)}$, Aunnurahman ${ }^{2)}$, Aswandi ${ }^{3)}$ \\ ${ }^{1)}$ Universitas Tanjungpura, Pontianak, Indonesia \\ E-mail:heripriyanto.pay@gmail.com \\ ${ }^{2)}$ Universitas Tanjungpura, Pontianak, Indonesia \\ E-mail: aunuruntan@gmail.com \\ ${ }^{2)}$ Universitas Tanjungpura, Pontianak, Indonesia \\ E-mail: aswandiwk@yahoo.com
}

\begin{abstract}
The importance of community and students' parents participation should be a serious concern for schools because without the support of participation from relevant parties (stakeholders), the quality and objectives of education as desired by all parties will not be easy to realize properly. This research is qualitative research with the type of case study. In this study, a number of data collection techniques will be used, namely participant observation techniques (participant observations), in-depth interviews, and documentation studies. Based on the research that has been done, the following results are obtained (1) School work program to encourage community and students' parents participation in the implementation of education in Sekayam 2 High School; (2) The forms of community and students' parents participation in the implementation of education in Sekayam 2 High School are physical and non-physical; (3) The supporting factors for community and students' parents participation in the implementation of education at Sekayam 2 High School, is the existence of a forum or access to participation, the willingness and ability, hopes of obtaining good and quality education, trust in schools, and positive response from the school; (4) The inhibiting factors of community and students' parents participation in administering education at State 2 Sekayam Senior High School, are places of residence that are far from school, the economic level is still relatively low, the view that education is the responsibility of the school, the socialization of work programs is not optimal school, and busyness of parents with their work; and (5) The level of community and students' parents participation in the implementation of education at Sekayam 2 High School, classified as low or passive.
\end{abstract}

Keywords: Participation; Education Implementation

\section{INTRODUCTION}

Education is a shared responsibility, between the government, the private sector / business world, the community, parents, professional organizations, Non-Governmental Organizations (NGOs / NGOs), and other relevant parties (education stakeholders). Schools as formal education institutions will experience obstacles in trying to provide quality education for students if they do not get support from the education stakeholders themselves. This can be understood because the school in carrying out the implementation of education, of course, faced with various problems, on the one hand, the school has limited ability to be able to overcome any problems it faces, on the other hand, the community and students' parents demand service quality education.

The quality of the performance of implementing education in schools is strongly influenced by the participation of stakeholders in education itself. Stakeholder participation is contained in the National Education System Law No. 20 of 2003 article 54 paragraph (1) that "the participation of the community in education includes the participation of individuals, groups, families, professional organizations, entrepreneurs, and community organizations in the implementation and 
quality control of education services." The presentation provides confirmation that the community and students' parents are part of education stakeholders that cannot be separated from the implementation of education in schools.

The expected participation of the community and students' parents here can be realized in various forms, but in general, the form of participation can be grouped into two forms, namely physical and non-physical. Physical participation can be in the form of funds, materials, and tools or equipment needed in the learning process. Whereas non-physical participation can take the form of criticism and suggestions, supervision of children in learning, creating a good learning culture. The community and students' parents participation in administering education in schools are certainly not necessarily easy to realize. This is because there are many opportunities and challenges that should be able to be addressed properly by the school so that participation can run well. But in general, these opportunities and challenges can be grouped into two factors, namely supporting factors and inhibiting factors for participation in the implementation of education in schools.

The driving factors of the community and students' parents to participate in the implementation of education in schools include the existence of trust, willingness, opportunity, and abilities possessed by the community and students' parents to assist the school in overcoming the problems experienced in the implementation of education. While the factors that can hinder the emergence of community and students' parents participation in the implementation of education, among them can be in the form of apathy, distrust, negative responses obtained, education level, economic level, and geographical conditions. From this statement, the school, in this case, must be able to address or get around so that the inhibiting factors can be minimized so that active participation is expected to be realized as it should.

The importance of community and students' parents participation should be a serious concern for schools because, without the support of participation from relevant parties (stakeholders), the quality and objectives of education as desired by all parties will not be easy to realize properly. However, if we look at the reality in the field, there are still many people and students' parents who have not realized the importance of their role in supporting efforts to improve the quality of education. This condition is generally more prevalent in areas that are still not fully touched by development with the people whose education and economic levels are still relatively low. This is in accordance with the opinion that "in developing countries, most families cannot be expected to help and direct student learning more, so students in developing countries spend less time learning. This is because many people / students' parents do not understand the fundamental meaning of their role in children's education "(Hoyneman and Loxley in Rodliyah, 2013: 51-52).

The same condition is also experienced by people in the area of Sanggau Regency, West Kalimantan, which is directly adjacent to neighboring countries, namely Malaysia, precisely in the Sarawak-Malaysia area. Sanggau Regency itself has fifteen sub-districts, and two of them are sub-districts bordering land with Malaysia, namely Sekayam and Entikong Districts. In contrast to Entikong Subdistrict, Sekayam Subdistrict is relatively better, because it has a high school level education or a complete equivalent. Namely, there are two State High Schools and one Private Vocational School (SMK).

Judging from the principal data of the school has shown that the government is currently trying to improve education in the Sekayam District. Among the two State High Schools in Sekayam Subdistrict, Sekayam 2 High School has more value, namely there is a dormitory for students built by the government to accommodate students who live far from school or who come from outside the Sekayam District, and is the only state high school in Sanggau District that has a dormitory for boarding students. But according to the information obtained from the Principal the concept of boarding school has not been fully implemented in Sekayam 2 High School, this can be observed from the construction of housing for educators and education staff as well as student dormitories which are still inadequate when viewed from the amount and capacity.

Based on the explanation above, the researcher decided to choose State 2 Sekayam Senior High School as the place for conducting the research. The election of Sekayam 2 High School is based on uniqueness, which is located in the border area and is the only high school state school in Sanggau District that applies the concept of boarding school (though not yet fully) in the implementation of education. The researcher was very interested in the concept of boarding school and participation which, according to the author, was one of the alternative solutions to solve the problem of education in the border area, especially in State 2 Sekayam Senior High School. This study wants to reveal adequate information about school work programs that encourage participation, forms of participation, supporting and inhibiting factors of participation, and how the level of community and students' parents participation in the implementation of education in Sekayam 2 High School. In this case, the researcher gave the title: "The Community and Students' parents Participation in Organizing Education in State 2 Sekayam Senior High School ".

\section{RESEARCH METHOD}


The research method is qualitative which is directed at the condition of natural objects. The rationale in this study, namely to examine community and students' parents participation in the implementation of education using a qualitative approach. Qualitative research is used on the grounds that the focus of research attention is on community and students' parents participation in the implementation of education in Sekayam 2 High School. The assessment of community and students' parents participation in the implementation of education requires research to draw meaning on the aspects of participation developed. In attracting this meaning, the researcher enters State 2 Sekayam Senior High School (research background) and acts as a key instrument.

This research is qualitative research, with a type of case study. In this study, a number of data collection techniques will be used, namely participant observation techniques (participant observations), indepth interviews, and documentation studies. Emzir (2012: 37) states that "Observation or observation can be defined as 'focused attention' to events, symptoms, or something." In line with the view that states, "Focused observations are specifically aimed at observing certain aspects of the musty ..." (Aunurrahman, 2014: 182). The objectives of the interview activities are those who are the subjects of research in the Sekayam 2 High School and in the surrounding community and students' parents. The documentation in this study is intended to obtain data relating to school work programs that encourage participation, forms of community participation, supporting factors, inhibiting factors, and the level of community and students' parents participation in the implementation of education in Sekayam 2 High School.

\section{RESULT AND DISCUSSION}

\section{A. Results}

Based on the results of interviews and observations supported by the documentation that has been carried out in order to express community and students' parents participation in the implementation of education in Sanggau 2 High School, the research findings are presented as follows.

1. School Work Program to Encourage Participation of Community and Students' parents in Organizing Education in State 2 Sekayam Senior High School

Based on the analysis carried out on the results of the study, State 2 Sekayam Senior High School has a work program in the form of vision, mission, objectives, RKS / RKAS, and KTSP which are formulated based on existing regulations and technical guidelines, taking into account the school's potential, input, and suggestions from all school residents to improve the quality of education. The vision, mission, goals, RKS / RKAS, and KTSP have been socialized to school residents and students' parents.

The formulation of the vision, mission, objectives, RKS / RKAS, and KTSP involves the principal, the teacher team, and the school committee. Formulation of the vision, mission, objectives, RKS / RKAS, and KTSP by considering the potential possessed by the school and based on regulations, provisions, and technical instructions on national education standards (SNP). The school work program to encourage community and students' parents participation in the implementation of education has been spelled out in the vision, mission, objectives, RKS, and KTSP that have been known and approved by the Head of the West Kalimantan Province Education and Culture Office. The vision, mission, goals, RKS/RKAS, and KTSP that are already owned by Sekayam 2 High School are still not fully known and understood by the community and students' parents, this is due to the involvement of the community and students' parents in the formulation of the school's work program has not fully gone well. In this case, the participation that occurs is still procedural participation and has not touched the substance aspect of the desired participation. On the other hand, the socialization carried out by the school was felt to be inadequate for the community and students' parents.

2. The forms of Community and Students' Parents Participation in Organizing Education in State 2 Sekayam Senior High School

Based on the analysis carried out on the results of the study, related to the form of community and students' parents participation in the implementation of education in Sekayam 2 High School, the research findings in the form of community and students' parents participation in the implementation of education already existed or have been conducted in State 2 Sekayam Senior High School, which is physical and nonphysical. The forms of participation are as follows (a) Participation is physical, in the form of funds, materials, equipment or media used in learning at school; (b) Participation takes the form of non-physical, in the form of criticism and suggestions, supports school activities, attendance at school if needed, creates a culture of good learning, participates in supervising student behavior, and motivates and directs students to learn. However, the participation of the community and parents of these students is still small and rarely done. Participation carried out by the community, and students' parents 
have occurred only because of requests from the school.

3. The Supporting Factors of Community and Students' Parents Participation in Organizing Education in State 2 Sekayam Senior High School

Based on the analysis of research results relating to the supporting factors of community and students' parents participation in the implementation of education in Sekayam 2 High School, research findings were obtained, namely the existence of a place or access provided by the school, awareness and ability, hopes of obtaining a quality education, trust in the school, and the positive response from the school. In addition, there were people and parents who stored cellphone numbers and WhatsApp (WA) principals and homerooms, also accommodated elements of the community and students' parents in the management structure of the school committee in Sekayam 2 High School.

4. The Inhibiting Factors of Community and Students' Parents Participation in Organizing Education in State 2 Sekayam Senior High School

The inhibiting factors of participation in administering education at State 2 Sekayam Senior High School include, among others, the low awareness of participation, the distance of residence far from school, the difficulty of access to transportation and communication, and the economic level of the community and many parents who are low. In addition, there are still many people, and students' parents who think that education is the responsibility of the government, lack of socialization of school work programs, and the busyness of parents with their work can also be a limiting factor for parents' participation in education in State 2 Sekayam Senior High School.

These factors are strengthened by documents in the form of student data which also contains information about the identity and background of the parents of the students concerned. From the research findings as described, it can be concluded that the factors described above can indeed be a limiting factor for participation in the implementation of education in Sekayam 2 High School.

5. The level of Community and Students' Parents Participation in Organizing Education in State 2 Sekayam Senior High School

The research findings regarding the level of community and students' parents participation in administering education at Sekayam 2 High School are still relatively low or passive. This is because the participation of the community and students' parents only occurs because of a request from the education institution (school). Participation that occurs is not due to awareness and own initiative to take responsibility for improving the quality of education in schools. The implementation of education is still seen as the responsibility of the government, and the community and parents should be entitled to obtain quality education.

\section{B. Discussion}

This discussion is based on the conclusions of the findings and theoretical perspectives of community and students' parents participation in the implementation of education in schools.

1. School Work Program to Encourage Community and Students' Parents Participation in Organizing Education in Sekayam 2 High School School work program to encourage community and students' parents participation in administering educators in Sekayam 2 High School, as follows.

a. School Vision

Based on the results of interviews, observation and documentation show a positive tendency that State 2 Sekayam Senior High School has a vision, and the school's vision is formulated by the school principal with the formulation team and school committee, in accordance with regulations, provisions, and applicable instructions. The school's vision is formulated based on the potential and objectives of the educator, both the objectives of the education unit and the national education goals and by considering input from all school citizens, the community and students' parents, as well as interested parties concerned. The school's vision has been socialized to all school members through teacher council meetings, to the community and students' parents at the opening of the new school year meetings / meetings, through writing permanently at the school entrance, baleho and print out the text posted on the bulletin board or school wall magazine.

The vision of State 2 Sekayam Senior High School which has been formulated, is written in the voice "Creating quality human resources so that they are able to face the challenges of life in the era of globalization." If examined from this vision, it is clear that the ideals of the school are to produce educational output in the form of human resources that are able to compete in the midst of competitive global life, in this case, competition between nations or countries. This is in the opinion of Wahyudi (2012: 20) which states that "Vision is a picture of the future regarding the state of the organization that is aspired to be an organization that is better, innovative, 
competitive and able to change the environment."

Based on this vision, it can be concluded that there have been school efforts to try to meet the needs of the community and students' parents in the border area, namely increasing the quality of human resources in order to compete with human resources in other countries, namely Sarawak-Malaysia. This can be understood because State 2 Sekayam Senior High School is one of the State High Schools in the sub-district that is directly adjacent to other countries, namely Malaysia. So it is clear that the needs of the community and students' parents in Sekayam Subdistrict are the need for human resources that are able to compete in social relations between nations (Indonesia-Malaysia).

School efforts to meet the needs of the community and students' parents are a form of school planning to be able to encourage community participation in the implementation of education in State 2 Sekayam Senior High School. With the hope that the community and students' parents are called to participate or participate in seeking to improve the quality of service delivery in school education. This is in line with the opinion expressed by Mamusung in Aedi and Rosalin (Teaching Education Lecturer Team of the Indonesian Education University, 2014: 279-2280), stating that "School as a social institution that is held and owned by the community should be able to meet the needs of the community and the school has a legal and formal obligation to provide information to the community about its objectives, programs, needs, and circumstances, and on the contrary the school must know clearly what needs, the expectations and demands of the people.

This opinion provides an understanding that the school's vision should be able to present that the implementation of education actually starts from, by, and for the benefit of the community and students' parents themselves, which ultimately will lead to the fulfillment of the needs of the nation in the form of superior human resources.

Based on the explanation above, it can be concluded that the vision of State 2 Sekayam Senior High School has a positive tendency to show that the vision includes school work programs to encourage community and students' parents participation in the implementation of education in schools.

b. School Mission
Based on the results of interviews, observation and documentation show a positive tendency that State 2 Sekayam Senior High School has a school mission. The formulation of the mission is by a team that has been determined in accordance with the applicable regulations and technical guidelines, based on the potential of the school, by considering criticism, suggestions, and input from all school members, the community and students' parents, and other educational stakeholders. The school's mission is also disseminated to all school members through teacher council meetings, to the community and students' parents through meetings or opening meetings for new school years, writing permanently to the left of the school entrance, baleho and print out the text posted on the bulletin board and school wall magazines.

As for the State 2 Sekayam Senior High School mission, namely (1) Faithful, devoted, moral and cultured; (2) Mastering science and technology; (3) Having life skills in the fields of skills, sports and art; and (4) Mastering and communicating fluently in English. This is in line with Mustari's opinion (2014: 16) which states that

Missions can also be interpreted as actions to meet the interests of each group related to school. In the formulation of the mission must consider the main tasks of the school and interest groups related to the school. In other words, the mission is a form of service to fulfill the demands set forth in the vision with various indicators.

In analyzing each point of the school mission, it is clear that the school has tried to provide services in accordance with the needs of the community and students' parents. The school's mission also means that the school also wants the community and students' parents to participate to ensure that the learning process of students can run well. This is in accordance with Mustari's opinion (2014: 154) stating that "The attitude of children toward school will mainly be influenced by the attitude of their parents. This is very important, considering that lately there have often been disrespectful actions taken by students, while parents don't seem to want to know, even tend to blame the school. Parents must pay attention to their child's school, namely by paying attention to their experiences and respecting all their efforts. Likewise, parents must show cooperation in directing the way children learn at home, motivating and guiding children in learning. 
Based on the above explanation, it can be concluded that the mission of State 2 Sekayam Senior High School has a positive tendency towards school efforts in encouraging community and students' parents participation in the implementation of education in schools.

c. School Objectives

The purpose of State 2 Sekayam Senior High School is prepared by a team that has been set based on existing regulations and technical instructions. The formulation of these objectives is based on the potential of the school and of course by considering criticism, suggestions, and input from all school members, the community and students' parents, and other educational stakeholders. The purpose of the school has been socialized to all school members through teacher council meetings, to the community and students' parents during meetings or meetings for the opening of the new school year, with writing neatly framed in the living room, as well as through baleho or printouts of pasted texts on bulletin boards and school wall magazines.

The purpose of the school refers to the vision and mission in the form of targets to be achieved from the implementation of education in schools. In addition to referring to the vision and mission, the purpose of education in each education unit must also refer to national education goals. The purpose of Sekayam State High School 2, namely (1) Belief and devotion to God Almighty; (2) Acting in the community as citizens of Pancasila; (3) behave in accordance with applicable norms and values; and (4) Having adequate knowledge, skills and environmental insights to live independently and / or follow further education.

Listening to the objectives of Sekayam State High School 2 above, it is clear that the school's goal to be achieved has shown the school's efforts to encourage community participation in the implementation of education in schools, it is understood from the meaning contained in each point in the school's goals. This is also in accordance with Minister of National Education Regulation Number 19 of 2007 concerning Education Management Standards by the Primary and Secondary Education Unit.

Based on the explanation, it can be concluded that this goal has shown a positive tendency as a school work program that can encourage community and students' parents participation in the implementation of education in Sekayam 2 High School.

d. School Work Plan (RKS / RKAS)

State 2 Sekayam Senior High School has a School Work Plan (RKS) and School Budget Work Plan (RKAS). In the formulation, it is in accordance with the applicable rules and regulations, which involves the principal, teacher team, school committee / students' parents, or community representatives who care about education. The RKS and RKAS have been disseminated to all school members through teacher council meetings, to school committees, communities and students' parents at new school year meetings or opening meetings, and in the form of documents that can be accessed at school.

Each activity in the education unit is based on the RKS which is a detailed elaboration of the Medium Term Work Plan (RKJM) of the education unit which covers a period of four years. This is in accordance with Government Regulation Number 32 of 2013 concerning National Education Standards. The formulation of school work programs must certainly involve relevant parties, in this case, education stakeholders. Thus educational institutions (schools) can accommodate the interests of each of the related parties (stakeholders), here are mainly community participation and students' parents. This is also in accordance with the opinion of Siagian in Rodliyah (2013: 82) stating that "Community participation in decision making is a process in choosing alternatives given by all elements of society, other social institutions."

Formulation of school work programs, RKS / RKAS, is based on applicable regulations, instructions and provisions, and by considering the conditions, potential, objectives of the education unit, and national education goals. Although the participation of the community and students' parents at Sekayam 2 High School shows a positive tendency that participation is only a manifestation of procedural regulations and instructions in the implementation and management of education in schools, there are basically school efforts to encourage community and students' parents participation in implementing education in schools. This is in accordance with the mandate of Law No. Article 20 of 2003 mandates that "The community has the right to participate in the planning, implementation, supervision, and evaluation of educational programs." However, if 
analyzed based on the results of the study revealed a positive tendency that the formulation of the RKS / RKAS has shown the existence of school efforts to encourage community and students' parents participation in the implementation of education in Sekayam 2 High School. The same view expressed by Doyle, Terry (2008: 23) states that "Participation in discussions is a great way to learn and can be emotive, socially, and intellectually rewarding." This means that participation in discussion is the best way to learn emotional, social, and intellectual.

RKS /RKAS Sekayam 2 High School is a list of planned activities designed to be carried out within a certain period. This RKS / RKAS will become a working guideline as well as a benchmark for performance achievement or accountability for the implementation of performance over a predetermined period in order to achieve the stated objectives. The RKS / RKAS formulations that have become school provisions have also been socialized to the school community through teacher council meetings as well as to the community and students' parents at school meetings with parents held at the beginning of the new school year. This is in line with the opinion expressed by Mamusung in Aedi and Rosalin (Indonesian Education Education Lecturer Lecturer Team, 2014: 279-2280), stating that "Schools as social institutions organized and owned by the community should be able to meet the needs of their community and schools legal and formal obligations to provide information to the community about the objectives, programs, needs and circumstances, and vice versa the school must know clearly what the needs, expectations, and demands of the community are. "

Based on the explanation above, it can be concluded that State 2 Sekayam Senior High School has RKS/RKAS formulated by teachers, principals, school committees, education councils, communities, and students' parents, based on laws, regulations, and provisions /existing technical instructions. RKS / RKAS State 2 Sekayam Senior High School has a positive tendency as a school work program that encourages community and students' parents participation in implementing education in schools.

\section{e. Education Unit Level Curriculum (KTSP)}

Based on the results of interviews, observation and documentation show a positive tendency that State 2 Sekayam
Senior High School has an Education Unit Level Curriculum (KTSP). In its formulation, it involves the principal, teacher team, school committee / students' parents, or community representatives who have concern for improving the quality of education, and by being known and approved by the Head of the Education and Culture Office of West Kalimantan Province in accordance with applicable regulations. The KTSP has been disseminated to all school members through teacher council meetings, to school committees, the community and students' parents at new school meetings or opening meetings, and in the form of documents that can be accessed at school.

KTSP Sekayam State 2 Sekayam Senior High School shows a positive trend with the presence of activities or work programs that show the school's efforts to encourage community and students' parents participation in the implementation of education in schools, as stated in Chapter I point 4 of the principle of developing the State 2 Sekayam Senior High School curriculum, precisely in point (a) which states that "Focusing on the potential development of the needs and interests of students and the environment", in Chapter II in the points of education goals, vision, mission, and objectives of the school, and contained in school activity planning which contains the plan "Plenary Meeting committee (new student OT) and meeting with parents ". To be clearer, plans for activities or work programs that will be carried out by the school can be seen in the KTSP document as attached to this study. In line with the opinion of Sagala (2006: 165) states that "In order for the implementation of more aspirational and effective education it is necessary to include the community and the community to become the main stakeholders of the education process. Public awareness of the quality control of education in schools is not only indicated by their willingness to help schools in physical form or in the cost of assistance. However, this concern needs to cover aspects related to the quality of learning services. "

Based on the explanation above, related to the work program of State 2 Sekayam Senior High School to encourage community and students' parents participation in the implementation of education, it can be concluded that the school work program is in the form of vision, mission, goals, RKS / RKAS, and KTSP as has been previously described, and educational institutions cannot just escape with education stakeholders, especially the 
community and students' parents. Schools desperately need community and students' parents participation. Therefore schools must continue to push for such participation to work properly. Schools must be able to innovate in formulating work programs that can accommodate needs and can attract the interest of the community to be able to take part in the implementation of education in schools. Therefore, partnership relationships based on common responsibilities and common goals should be able to become a potential for relevant parties in seeking to improve the quality of education. This is in accordance with Mustari's opinion (2014: 155) which states that with the basis of similarity of responsibilities and similarity of objectives, the cooperation between the family and the school aims to help and complement each other, financial and goods assistance, and to prevent bad deeds, for example not playing the film at the time of the lesson, and so on.

2. The Forms of Community and Students' Parents Participation in Organizing Education in State 2 Sekayam Senior High School

Based on the results of interviews, observation and documentation, it shows a positive tendency that there has been community and students' parents participation in the implementation of education in Sekayam 2 High School, namely participation in the form of physical and non-physical. This is in accordance with the opinion expressed by Basrowi in Dwiningrum (2015: 58) stating that

Community participation seen from its form can be divided into two, namely nonphysical participation and physical participation. Physical participation is community participation (parents) in the form of organizing school businesses and organizing scholarship businesses, helping the government build buildings for the community, and organizing library businesses in the form of books or other assistance. Whereas non-physical participation is participation in determining the direction of national education and the prevalence of public interest to demand knowledge through education so that the government has no difficulty directing the people to go to school.

Community and students' parents participation in administering education at State 2 Sekayam Senior High School in the form of physical participation, namely in the form of funds, materials or building materials, equipment or learning equipment for students, and providing facilities and infrastructure that can support the learning process of students. A view that is not much different is also expressed by
Sastropoetro in Rodliyah (2013: 39-40), which states that the form of community participation is (a) Consultation, usually in the form of services; (b) Spontaneous contributions in the form of money and goods; (c) Establishing self-supporting projects and donors derived from donations of individuals / institutions that are outside a certain environment (third parties); (d) Establish projects that are self-sufficient and funded entirely by the community; (e) Donations in the form of work; (f) mass action; (g) Establish development among independent village families; and (h) Building autonomous community projects.

Whereas non-physical participation in

State 2 Sekayam Senior High School, has a positive tendency in the form of criticism and suggestions, supports and encourages students to take part in activities carried out by the school, the presence of the community and students' parents at school if needed by the school (time), creating a culture of learning that is good in the community and at home, participates in supervising the behavior of students in the community and at home, motivates and directs students in learning, and participates in supervising and guiding learners at home. This is in accordance with the opinion of Rodliyah (2013: 36-39) stating that community participation in education that is highly expected by schools is "(a) Supervising / guiding children's habits at home; (b) Guiding and supporting children's academic activities; (c) Giving encouragement to research, discuss ideas and / or actual events; (d) Directing children's academic aspirations and expectations. The same view also expressed by Dwiningrum (2015: 66$67)$ states that the role of parents in forming a conducive learning environment at home includes

(a) Creating a culture of learning at home; (b) Prioritizing tasks that are directly related to learning in school; (c) Encouraging children to be active in various activities of school organizations, both curricular and extracurricular; (d) Provide opportunities for children to develop ideas, ideas, and various activities that support learning activities; (e) Creating a democratic situation at home to exchange opinions and thoughts as a means of learning and learning; (f) Understanding what has been, is, and will be done by the school, in developing the potential of their children; and (g) Providing adequate learning facilities, in accordance with the abilities of parents and school needs.

Another positive trend that shows the form of community and students' parents 
participation in State 2 Sekayam Senior High School, namely the musholla building, a set of internet networks, 40 mattresses, books, and a set of mini studios which are assistance from PT ASABRI (Persero) Jakarta. The house of worship is a chapel (small church) built from sharing funds between the community, students' parents and the school for the purposes of worship for students who are Catholic and Christian. Besides that, there are also tools for cooking which are assistance from the community and students' parents to the school, which are used by students in practicing cooking skills at school. The condition that occurs in Sekayam 2 High School is in accordance with the opinion expressed, that "First, that community participation in development is not the mobilization of the people in development. People's participation in development is cooperation between the people and the government to design, implement and finance development "(Soetrisno in Ramaniah, 2015: 50).

In addition to positive trends, the results of the study also indicate a negative tendency, namely the form of community and students' parents participation in the implementation of education in Sekayam 2 High School is still little or relatively rare. The form of participation that exists or is carried out by the community and students' parents has occurred only because of the encouragement in the form of requests from the school. This condition should not occur, even if it is not desired in participation. In other words, it should occur because of the awareness that these are rights, obligations, and responsibilities, which in the end will also contribute positively to the interests of the community and parents of the students themselves. This is in line with the opinion expressed by Ife in Ramaniah (2015: 47), stating that "... empowerment means providing people with the resources, opportunities, knowledge, and skill to increase their capacity to determine their own future, and to participate in and affect the life of their community ". With participation, the community and students' parents who are expected to be able to, that they really need education and education also need them to strive for quality improvement.

Based on the description above, it can be concluded that the forms of community and students' parents participation have occurred in State 2 Sekayam Senior High School, in general, the participation can be classified into physical and non-physical forms. The participation was carried out by the community and students' parents because there was a request from the school as a form of mutual responsibility in seeking to improve the quality of education in schools. Sekayam 2 High School, in this case, should be able to utilize all forms of community and parents of existing students participation to improve the quality of education for students further. Thus it will increase community trust in educational institutions (schools) so that it will have an impact on the growing awareness of the community and students' parents to participate in the implementation of education in schools. The level of trust and awareness will encourage schools, communities, and students' parents to build harmonious partnerships in seeking to improve the quality of education in schools.

3. Supporting Factors of Community and Students' Parents Participation in Organizing Education in State 2 Sekayam Senior High School

Supporting factors for community participation and students' parents in the implementation of education at Sekayam 2 Senior High School can be seen from the existence of a forum and access to participation, willingness and ability, hopes of obtaining quality education, trust in schools, and positive responses from schools.

When viewed from the factor of the existence of a forum and access to participation, it is very clear that it will encourage participation. With the container and access, the community and students' parents can communicate with the school, in this case, they can submit criticism and suggestions for the progress of the school. This is in accordance with the opinions of Aedi and Rosalin (Indonesian Education University Education Lecturer Team, 2014: 278), which states that "The relationship between the school and the community will produce results in the form of cooperation, and the collaboration can be carried out well if there is conducive communication that leads to fulfill their needs ". Based on the findings of the existence of the community and students' parents who store telephone numbers and WhatsApp (wa) principals and one of the teachers or homerooms of students, it is clear that the existence of a forum and access can be a supporting factor for participation. Thus it will affect the desire to participate in accordance with the abilities possessed by the community and students' parents, which is certainly based on the hope of being able to obtain quality education from the school. This is in accordance with the opinions expressed by Rodliyah (2013: 52-54) suggesting that as for the things that can be done to increase parental and community participation is

a. Schools must really show the sincerity of their efforts to obtain, maintain, improve, or 
improve their image in the eyes of the community and parents.

b. Schools involve parents and the community in making school planning, even if parents need to be given the authority to arrange some school activities.

c. The school must be open.

d. Schools also need to provide information to parents about what parents need to do in helping to educate their children.

The above view is reaffirmed by the opinion stating that the factors that influence community participation are (a) Gender; (b) Education level; (c) Income level; and (d) Livelihoods / employment (Slamet in Rodliyah, 2013: 56-58). Through well-established communication will have an impact on the opportunity for the community and students' parents to convey with what there are a desire and hope for educational institutions (schools). Thus the school will understand the condition of the community and students' parents so that the school will respond by trying to fulfill what the community and parents want and hope for. The fulfillment of the wishes and expectations of the parents of the students will ultimately encourage the trust of the community and students' parents towards educational institutions (schools), which in turn will encourage their desire to participate in the implementation of education in schools. This is in line with the opinions of Aedi and Rosalin (Lecturer Team of Indonesian Education Education Administration, 2014: 277) also states that "The growth of community trust also implies the insistence of the institution's needs on developing in order to answer the challenges and needs of society so that in turn the community will determine the choice of which institution is feasible to be given the trust to educate the community of students ".

This view also affirms that in understanding social capital needed in education is the existence of "trust" and participation. Therefore, participation is considered an asset, so it needs to be developed optimally to achieve quality objectives. Furthermore, quality objectives can be achieved if there is participation and "trust" from the community to the school as a form of social capital. Another aspect that needs to be considered in order to increase the trustworthiness of the community and students' parents is the factor of transparency and accountability, without the support of these factors it will be difficult to gain trust. This is in line with the views of Ratminto and Winarsih (2006: 208) stating that "Transparency and accountability must be implemented in all aspects of public service management, including policy, planning, implementation, supervision / control, and reports on performance results." Furthermore, Sheldrake and Lingke in Sagala (2006: 248) state that in the implementation of education, the accountability movement is initially triggered by two interests that need to be considered "First, it involves the accountability of the use of budget costs invested in the implementation of education. While the second concerns the even distribution of education for the occupation of a country. Thus, it is clear that the demands of the community for education accountability that deal with quality and relevance remain concerned about efficiency and equity. "

4. The Inhibiting Factors Community and Students' Parents Participation in Organizing Education in State 2 Sekayam Senior High School

Based on the results of interviews and documentation shows a positive tendency that there are factors that inhibit community participation and students' parents in the implementation of education in State 2 Sekayam Senior High School. The inhibiting factors of participation are low awareness of participation, shelter far from schools with relatively difficult access to transportation and communication, low economic level, lack of socialization of school work programs, and busyness of parents with their jobs. This is in accordance with the opinion expressed by Dwiningrum (2015: 57-58) which states that factors that can inhibit or become a threat to community participation, as follows.

a. Lazy, apathetic, ignorant, and unwilling to make changes at the level of community members.

b. Typological aspects (proof and cliff).

c. Geographical (small islands scattered).

d. Demographics (population).

e. Economy (poor / disadvantaged villages).

Based on these opinions, it provides an understanding that the factor of low awareness of participation, housing that is far from the school with access to transportation and communication is relatively difficult, and the economic level is still relatively low, can be factors that inhibit community and students' parents participation in organizing education in Sekayam 2 High School so that the impact on the difficulty of the school involved the community and students' parents in seeking solutions to overcome the limitations experienced by the school in seeking to improve the quality of the implementation of quality education in schools.

Another positive trend is the view that education is the responsibility of the government, the lack of socialization of school work programs, and the busyness of parents in working are also included in the inhibiting factors of community and students' parents 
participation in the implementation of education in Sekayam 2 High School. This is in accordance with the opinion of Hamijoyo in Rahmawati (2012, p.37) which states that the inhibiting factors of community participation are as follows.

a. The community has not been able to live or feel the problem or its interests.

b. The purpose of community participation is less clear, perhaps because the benefits or objectives of development are not clear to the community.

c. There are no organizations and leaders who are reliable enough to manage community participation so that the aspirations and potential of citizens are not channeled effectively and efficiently.

Participation requires the same understanding or objectivity of school and parents in school goals. This means that participation is not sufficiently understood by schools as an important part of school success in improving quality, because quality objectives are difficult to obtain if understanding in intersubjective worlds (students, parents, teachers) shows knowledge gaps about quality. That is, community participation in quality improvement is successful if there is a common understanding between schools and families in making high achieving children (Dwiningrum, 2015: 193).

A good partnership relationship between the school and the community and students' parents is needed to be able to anticipate the inhibiting factors experienced by each of the parties concerned. With a good partnership relationship, each party can openly express problems that prevent them from participating with each other. The openness of each related party is a way to be able to understand each other and analyze the right alternative solutions to be able to address the inhibiting factors of such participation.

5. The Level of Community and Students' Parents Participation in Organizing Education in State 2 Sekayam Senior High School

Based on the results of interviews and documentation shows a positive tendency that there has been or has occurred community and students' parents participation in the implementation of education in State 2 Sekayam Senior High School. Sagala (2006: 162) states that "Schools that implement school-based management have characteristics of high school and community participation. This is based on the belief that the higher the level of participation, the greater the sense of belonging followed by greater sense of responsibility and so on the greater the level of dedication ". The statement provides an understanding that participation greatly influences the ability of educational institutions (schools) to strive to create quality teaching and learning processes for their students.

However, the facts show a negative tendency, namely the level of community and students' parents participation in the implementation of education in Sekayam 2 High School is still in the low category. This is in accordance with the views of Club Du Sahel in Rodliyah (2013: 50-51) arguing that the participation rate is as follows

a. Passive Participation, Training, and Information. This participation is a type of one-way communication such as the direction between teacher and student.

b. Active participation. This participation is a dialogue and two-way communication by providing opportunities for the community to interact with extension officers and outside training.

c. Participation with Linkages. Local people, both individuals, and groups are given a choice to be responsible for every community activity and project.

d. Participation in Local Requests. Project activities are more focused on addressing the needs of the local community, not needs to be designed and voiced by outsiders.

If based on the above opinion, it clearly provides an understanding that community and students' parents participation in the implementation of education in Sekayam 2 High School is included in the level of passive participation. This means that the participation that occurred in State 2 Sekayam Senior High School was only because there was a request from the school, and not because of their own initiative from the community and students' parents. Another negative trend that triggers the low level of participation is that participation in State 2 Sekayam Senior High School is not a form of awareness to help schools in pursuing the provision of quality education, but occurs only in procedural rules or regulations.

This is in accordance with the opinion of Shery Arstein in Dwiningrum (2015: 64), who argues that if it is associated with the level of power given to the community associated with participation, then the participation of the community in planning can be divided into the following steps.

Table I

Participation Ladder 


\begin{tabular}{clr}
\hline CLASSIFICATION & \multicolumn{1}{c}{ DESCRIPTION } & LEVEL \\
\hline Citizen Power & $\begin{array}{l}\text { At this stage there has been a } \\
\text { distribution of rights, responsibilities } \\
\text { and authority between the community } \\
\text { and the government in making } \\
\text { decisions. }\end{array}$ & $\begin{array}{r}\text { Citizen Cont } \\
\text { Delegated Cor } \\
\text { Partnnershil }\end{array}$ \\
\hline Tokenism & $\begin{array}{l}\text { It is only a formality that allows people } \\
\text { to hear and have the right to vote, but } \\
\text { their opinions have not become } \\
\text { material in the decision making } \\
\text { process. }\end{array}$ & $\begin{array}{c}\text { Placation } \\
\text { Information }\end{array}$ \\
\hline Non Participation & Society is only used as an object. & $\begin{array}{c}\text { Therapy } \\
\text { Manipulatio }\end{array}$ \\
\hline
\end{tabular}

Source: Dwiningrum (2015: 64)

If examined from the opinion of Shery Arstein presented in Table I Staircase Participation above, it is clear that community and students' parents participation in the implementation of education in Sekayam 2 High School are included in the Tokenism ladder level, which means that participation occurs only as a formality.

Responding to the low level of community and students' parents participation in the implementation of education, schools should be able to optimize work programs that can encourage participation. Schools should be creative and have innovations in formulating superior programs that are characteristic of schools, which of course are in accordance with the needs of the community and students' parents. For this reason, the school can optimize the role and function of the school committee, which is a formal and legal forum for representatives of the community and students' parents in designing the tuition programs. This is in accordance with the opinion of Rodliyah (2013: 84) stating that in carrying out their duties, the school committee acts as:

a. Advisory agency or consideration in determining and implementing education policies in educational units;

b. Supporting agencies or supporters, both in the form of financial, thought and energy in the implementation of education in educational units;

c. Controlling agency or controller in the context of transparency and accountability in implementing education in educational units;

d. Mediator or intermediary between the government (executive) and the community in the education unit.

If it is analyzed from the task of the school committee, it is clear that the existence of a school committee in each education unit will provide the potential for the school to respond to any problems it faces. Of course, the school committee must be involved in every stage of the implementation of education by building good and harmonious partnerships so that the committee will truly feel valued and needed by the school.

\section{CONCLUSION}

A. Conclusions

Based on the results of research findings and discussions about community and students' parents participation in the implementation of education in Sekayam 2 High School, conclusions can be drawn as follows.

1. School work program to encourage community and students' parents participation in implementing education at Sekayam 2 High School, including in the form of vision, mission, goals, RKS / RKAS, and KTSP.

2. The form of community and students' parents participation in the implementation of education in Sekayam 2 High School, namely in the form of physical and non-physical.

3. Supporting factors for community and students' parents participation in administering education at State 2 Sekayam Senior High School, is the existence of a forum or access to participate, the willingness and ability, hope to obtain a good and quality education, trust in the school, and the existence positive response from the school.

4. The inhibiting factors of community and students' parents participation in administering education at State 2 Sekayam Senior High School, are places of residence that are far from schools with relatively difficult access to transportation and communication, the economic level is still relatively low, the view that education is the responsibility school answer, lack of maximum socialization of school work programs, and busyness of parents with their jobs.

5. The level of community and students' parents participation in administering education at State 2 Sekayam Senior High School, classified as low or passive.

B. Suggestions

Based on the findings of the research described above, some suggestions and recommendations can be given as follows.

1. Schools are expected to be able to accommodate the interests and needs of education stakeholders through activities contained in the school work program.

2. The form of community and students' parents participation should be directed to improve the effectiveness and efficiency of the implementation of the teaching and learning process in schools. 
3. The supporting factors for community $x$ and students' parents participation are optimally utilized.

4. Establishing good communication between school, community, and students' parents.

5. Building good and harmonious partnerships between schools and school committees, as well as more empowering the roles and functions of school committees.

\section{REFERENCES}

Aunurrahman. 2014. Penelitian Tindakan KelasPanduan Bagi Guru, Calon Guru, dan Instruktur (Edisi Revisi). Pontianak: STAIN Pontianak Press.

Dwiningrum, Astuti, Siti Irene. 2015. Desentralisasi dan Partisipasi Masyarakat dalam Pendidikan. Yogyakarta: Pustaka Pelajar.

Mustari, Mohamad. 2014. Manajemen Pendidikan. Jakarta: PT RajaGrafindo Persada.

Rahmawati, Sufa, Diana. 2012. Partisipasi Masyarakat Dalam Pelayanan Pendidikan di SDN Cibeusi dan SDN Jatinangor. Tesis Pascasarjana FISIP. Ilmu Adminstrasi Universitas Indonesia.

Rodliyah, St. 2013. Partisipasi Masyarakat dalam Pengambilan Keputusan dan Perencanaan di Sekolah. Yogyakarta: Pustaka Pelajar dan STAIN Jember Press.

Sagala, Syaiful. 2006. Manajemen Berbasis Sekolah dan Masyarakat Strategi Memenangkan Persaingan Mutu. Jakarta: PT Nimas Multima.

Tim Dosen Administrasi Pendidikan Universitas Pendidikan Indonesia. 2014. Manajemen Pendidikan. Bandung: Alfabeta.

Undang-Undang Republik Indonesia No. 20 Tahun 2003. Tentang Sistem Pendidikan Nasional. Bandung: Citra Umbara.

Wahyudi. 2012. Kepemimpinan Kepala Sekolah dalam Organisasi Pembelajar. Bandung: Alfabeta. 